\title{
LAPORAN PENGABDIAN MASYARAKAT TENTANG \\ BIMBINGAN DAN PELATIHAN TENTANG PENGEMBANGAN SOFT SKILL (MENEMUKAN POTENSI DIRI) BAGI ANAK BERKEBUTUHAN KHUSUS DI YAYASAN PEMBINAAN ANAK CACAT (YPAC) MALANG
}

Lilies Nur Ainie ${ }^{1}$

Nilawati Fiernaningsih $^{2}$ Siti Nurbaya ${ }^{3}$

Mustofa Hadi ${ }^{4}$

Halid Hasan ${ }^{5}$

${ }^{1}$ lilies.nur@polinema.ac.id

${ }^{2}$ nilafh@polinema.ac.id

${ }^{3}$ siti.nurbaya@polinema.ac.id

4 mustofa.hadi@polinema.ac.id

${ }^{5}$ halid.hasan@polinema.ac.id

\begin{abstract}
Abstrak
Tujuan dari kegiatan ini untuk memberikan bimbingan dan pelatihan tentang pengembangan soft skill bagi anak berkebutuhan khusus, Meningkatkan soft skill, dan cara menemukan potensi diri pada anak berkebutuhan khusus, Membantu memberikan pemahaman bahwa pengembangan soft skill.

Kegiatan ini merupakan kegiatan pengabdian masyarakat (PKM) dengan bentuk kegiatan dilakukan dengan materi sebagai berikut: Materi edukasi, Perlombaan, dan Pembahasan Masalah.

Hasil dari kegiatan ini adalah meningkatkan wacana peserta pelajar Yayasan Pembinaan Anak Cacat (YPAC) Malang, Meningkatkan ilmu pengetahuan anggota terhadap ketrampilan dasar yang dipilih dengan beberapa pertimbangan khusus yaitu menemukan potensi diri dari soft skill yang dikuasai, dan Meningkatkan hubungan antara Politeknik Negeri Malang dengan masyarakat, khususnya di Yayasan Pembinaan Anak Cacat (YPAC) Malang.

Kata-kata kunci: bimbingan; pelatihan; pengembangan soft skill.
\end{abstract}

\section{Abstract}

The purpose of this activity is to provide guidance and training on developing soft skills for children with special needs, improving soft skills, and how to find their potential in children with special needs, helping provide an understanding that the development of soft skills.

This activity is a community service activity (PKM) with the form of activities carried out with the following material: Educational Materials, Contest, and Discussion of Problems.

The results of this activity are to improve the discourse of the participants of the Malang Disability Child Development Foundation (YPAC), Improve the members knowledge of selected basic skills with some special considerations, namely discovering the potential of the soft skills mastered, and Improving the relationship between Malang State Polytechnic and the community, especially in the Malang Disability Development Foundation (YPAC).

Keywords : guidance; training; developing soft skills

\section{Pendahuluan}

\subsection{Latar Belakang}

Kondisi yang tidak sempurna membuat penyandang difabel memiliki keterbatasan dan hambatan dalam menjalani kehidupan dan memenuhi kebutuhannya. Beberapa alat bantu diperlukan oleh para penyandang difabel untuk mempermudah aktivitasnya, seperti tongkat, buku-buku Braille, dan kaca mata bantu untuk penyandang difabel yang memiliki kelainan pada penglihatan. Kruk dan kursi roda untuk yang memiliki kelainan lain seperti cacat kaki agar dapat berjalan melakukan aktivitasnya, dan masih banyak lagi.

Hal yang tidak kalah penting adalah dukungan psikis dari orang-orang terdekat dan masyarakat sekitar, yang akan membuat mereka lebih dapat menerima kondisi fisiknya lebih tabah dan lebih siap menghadapi lingkungan. Sedangkan individu yang mengalami kecacatan setelah lahir akan mengalami tekanan psikologis yang berat saat 
mereka mulai dewasa, dikarenakan setelah terjadi kecelakaan dan divonis cacat mereka seperti tidak memiliki tujuan hidup lagi, diskriminasi oleh lingkungan.

Maka pendekatan serta peningkatan kepedulian terhadap penyandang difabel sangat diperlukan guna memunculkan kembali semangat dan sebagai dorongan bagi penyandang difabel untuk tetap menjalani kehidupan.

\subsection{Rumusan Masalah}

Bagaimana membangun kepercayaan diri melalui bakat dan potensi yang dimiliki penyandang difabel untuk berkomunikasi dengan lingkungannya bagi anak berkebutuhan khusus YPAC Malang.

\section{Tinjauan Pustaka}

\subsection{Pengertian Softkills}

Softskills merupakan tingkah laku personal dan interpersonal yang dapat mengembangkan dan memaksimalkan kinerja manusia melalui pelatihan, pengembangan kerja sama tim, insiatif, pengambilan keputusan lainnya (Diknas, 2008)

\subsection{Atribut Softkills}

Menurut Nursalam (2006), terdapat beberapa atribut softkills, yaitu menunjukkan hubungan interpersonal yang efektif, menunjukkan strategi manajemen diri, bekerja sama dalam tim, penyelesaian permasalahan secara kreatif, pengambilan keputusan, berkooperasi dengan yang lain, interaktif di tempat kerja, bertanggungjawab terhadap perusahaan, terbuka menerima bimbingan, mampu bekerja pada lingkungan yang beragam, mampu meresolusikan konflik.

\subsection{Jenis Keterampilan Softkills}

Dua jenis keterampilan softkills menurut Efendi (2011) adalah sebagai berikut: Interpersonal skill, yang meliputi Keterampilan komunikasi, Membangun hubungan, Keterampilan kepemimpinan, dan Kemampuan negoisasi.

Keterampilan Softkills yang kedua adalah Intrapersonal Skills, yang meliputi Manajemen waktu, Manajemen stres, Transformasi karakter, Proses berfikir kreatif, dan Manajemen perubahan.

\subsection{Manfaat Softkills}

Softskill mempunyai manfaat dan peranan yang besar dalam mendukung kesuksesan seseorang dalam memasuki dunia kerja, karena jika hanya mempunyai softskill yang baik tanpa dukungan dengan kepribadian atau soft skill yang baik maka semua akan siasia (Ismail, 2007).

\subsection{Karakteristik kompetensi Softkill}

Terdapat 4 hal yang merupakan karakteristik kompetensi, antara lain: Motivasi, Sifat bawaan, Konsep diri, Pengetahuan, dan Keahlian (Skill).

\subsection{Pengertian Mengembangkan Kepercayaan Diri}

Menurut Centi (1993:9) konsep diri adalah gagasan seseorang tentang diri sendiri, yang memberikan gambaran kepada seseorang mengenai dirinya sendiri.

\subsection{Manfaat Dalam Mengembangkan Kepercayaan Diri}

Menjadikan orang yang menghargai waktu, Hidup akan terkontrol melalui manajemen hidup yang baik, dan Memiliki pandangan hidup yang luas.

\subsection{Cara Meningkatkan Kepercayaan Diri}

Berhenti memikirkan apa yang orang lain pikirkan tentang anda, Belajar bagaimana menjadi yakin, Pandang diri secara positif, Tingkatkan pengetahuan dan keterampilan, dan Terbuka terhadap kritik dan saran.

\subsection{Mengenal Potensi Diri}

Setiap manusia memiliki bermacammacam potensi diri yang dapat dikembangkan. Secara garis besar, kecerdasan yang dimiliki manusia ada tiga macam, yaitu: Kecerdasan intelektual (IQ), Kecerdasan emosional (EQ), Kecerdasan spiritual (SQ).

\subsection{Pengertian Potensi Diri}

Potensi diri adalah kemampuan yang dimiliki oleh seseorang, baik fisik maupun mental dan mempunyai kemungkinan untuk dikembangkan bila dilatih dan ditunjang dengan sarana yang baik. Sedangkan diri adalah seperangkat proses atau ciri-ciri proses fisik, prilaku dan psikologis yang dimiliki.

\subsection{Jenis Bakat dan Klasifikasi Potensi Diri}

Secara umum, potensi memiliki klasifikasi sebagai berikut: Kemampuan dasar, Etos kerja, dan Kepribadian. Sedangkan menurut "Howard Gardner", terdapat beberapa potensi atau bakat yang terpenting, yaitu Intelegensi linguistik, Intelegensi matematislogis, Intelegensi ruang, Intelegensi kinestetikbadani, dan masih banyak lagi.

\subsection{Petingnya Memahami Potensi Diri}

Memahami potensi diri itu sangatlah penting, sebab dengan memahami dan mengetahui potensi yang dimiliki, dapat membantu meningkatkan kinerja (produktifitas) 
kita lebih baik lagi dari apa yang kita lakukan sehari-hari dalam hidup.

\subsection{Pengertian Kepribadian}

Kepribadian meliputi berbagai unsur, baik jasmani maupun rohani yang merupakan usaha seseorang dalam merealisasikan diri sebagai manusia seutuhnya yang tercermin dalam tingkah laku.

\subsection{Usaha Untuk Membina Kepribadian}

Terdapat beberapa usaha untuk membina kepribadian, antara lain: Belajar sepanjang hayat, Memerankan peran hidup, Mengekfektifkan hidup, Memahami etiket, dan lain-lain.

\subsection{Hambatan Dalam Pengembangan Pribadi}

Tidak memiliki tujuan hidup yang tergambar dengan jelas, kurang termotivasi untuk memobilisasi kemampuan yang ada pada dirinya, Enggan untuk mengenali dirinya, dan masih banyak lagi.

\subsection{Cara Untuk Membentuk Kepribadian}

Beberapa rasa yang harus ditanamkan semenjak kecil agar dapat membentuk kepribadian yang sehat, antara lain: Empati, Positive Thinking, Bertanggung jawab, Mampu mengakui kesalahannya kepada orang lain, Memaafkan kesalahan orang lain, Berpikir rasional, dan Mampu bersosialisasi dengan baik.

\section{Tujuan dan Mafaat Kegiatan \\ 3.1. Tujuan Kegiatan}

Memberikan bimbingan dan pelatihan tentang pengembangan soft skill bagi anak berkebutuhan khusus, Meningkatkan soft skill, dan cara menemukan potensi diri pada anak berkebutuhan khusus, Membantu memberikan pemahaman bahwa pengembangan soft skill.

\subsection{Manfaat Kegiatan}

Terjalinnya kerjasama dengan pihak luar dan sebagai salah satu bentuk kepedulian Politeknik Negeri Malang pada masyarakat luas untuk sharing dan penambahan pengetahuan serta sharing ilmu tentang pengembangan soft skill yang baik bagi anak berkebutuhan khusus untuk menghadapi pandangan masyarakat.

\section{Materi dan Metode \\ 4.1 Khalayak Sasaran}

Sebagai sarana dalam kegiatan Pengabdian Kepada Masyarakat (PKM) ini adalah para anak berkebutuhan khusus YPAC Malang.

\subsection{Metode Pengabdian Kepada Masyarakat (PKM)}

Bentuk kegiatan dilakukan dengan materi sebagai berikut: Materi edukasi, Perlombaan, dan Pembahasan Masalah.

\subsection{Materi Pengembangan Soft Skill Dengan} Teknik Memberikan Tekanan Lebih

Materi pengembangan soft skill diberikan dengan cara mengembangkan soft skill dengan memberikan tekanan pada diri sendiri. (4.3)

\subsubsection{Isi Materi Pengembangan Soft Skill}

Penyampean materi ditekankan pada perlunya pengembangan soft skill kepada setiap SDM yang ada di Indonesia. Melihat pentingnya SDM dengan tidak melihat fisik setiap orang yang ada di Indonesia, maka pengembangan soft skill diperlukan agar siap menghadapi tantangan dunia.

\subsubsection{Cara Pengembangan Soft Skill}

Cara pengembangan soft skill dengan melakukan praktek langsung melalui uji kebolehan setiap peserta. Uji kebolehan ini ditampilkan setiap peserta melalui media musik, menggambar dan membentuk kertas yang menjadi keahlian mereka.

\subsubsection{Dokumentasi Pengembangan Soft Skill}

\subsubsection{Proses Penyampaian Materi}

Bimbingan dan pelatihan tentang pengembangan soft skill (menemukan potensi diri) ini dilaksanakan di YPAC kota Malang dengan diikuti oleh siswa khalayak sasaran, pengajar khalayak sasaran, tenaga pembantu, dan narasumber.

\subsubsection{Uji Soft Skill Peserta}

Pada praktek atas dilaksanakan kegiatan bimbingan dan pelatihan tentang pengembangan soft skill (menemukan potensi diri) ini dilaksanakan di YPAC kota Malang dengan dilaksanakannya rangkaian tunjuk kebolehan mengenai potensi yang dimiliki.

\subsection{Rancangan Evaluasi}

\subsubsection{Evaluasi Sebelum Kegiatan PKM}

Menganalisis situasi dengan menjadikan khalayak sasaran sebagai peserta lomba dengan bakat-bakat yang dimiliki dan menilai bakat yang ditampilkan tersebut dengan cara yang sama dengan penilaian lomba anak pada umumnya, tidak memandang adanya keterbatasan yang dimiliki.

\subsubsection{Evaluasi Selama Kegiatan PKM}

Beberapa evaluasi pada kegiatan PKM adalah sebagai berikut: Evaluasi terhadap materi yang disampaikan, Evaluasi terhadap persepsi yang terbentuk dari khalayak sasaran, 
Evaluasi terhadap sikap menerima dan mendukung pada materi usulan yang disampaikan.

\subsubsection{Evaluasi Akhir Kegiatan PKM}

Pada evaluasi akhir kegiatan PKM, dapat diambil kesimpulan apakah kegiatan PKM memberikan kontribusi dan manfaat serta sesuai dengan institusi dimana kegiatan PKM dilaksanakan.

\section{Hasil dan Pembahasan}

\subsection{Hasil}

Meningkatkan wacana peserta pelajar Yayasan Pembinaan Anak Cacat (YPAC) Malang terhadap peluang untuk ikut serta dalam potensi di masyarakat, Meningkatkan ilmu pengetahuan anggota terhadap ketrampilan dasar yang dipilih dengan beberapa pertimbangan khusus (relatif mudah dipelajari dan memberikan kepercayaan lebih) yaitu menemukan potensi diri dari soft skill yang dikuasai, dan Meningkatkan hubungan antara Politeknik Negeri Malang dengan masyarakat, khususnya di Yayasan Pembinaan Anak Cacat (YPAC) Malang

\subsection{Pembahasan}

\subsection{Faktor Penghambat}

Khalayak sasaran adalah anak berkebutuhan khusus denganketerbatasan berbeda beda dan memiliki tingkah yang lebih aktif dari pada anak pada umumnya.

\subsubsection{Faktor Pendorong}

Melihat potensi besar yang dimiliki khalayak sasaran dalam mengema

\section{Simpulan dan Saran 6.1 Simpulan}

Keterbatasan membuat penyandang difabel memiliki hambatan dalam menjalani kegiatan untuk memenuhi kebutuhannya, dan memerlukan dukungan secara psikis dari orang terdekat maupun masyarakat sekitar. Maka dari itu, dilakukan lah kegiatan Pengabdian Kepada Masyarakat (PKM) ini melibatkan para anak berkebutuhan khusus YPAC Malang.

Kegiatan dilakukan dengan pemberian materi edukasi berupa motivasi dan pemateri memberikan contoh-contoh untuk mengembangkankan bakat. Selain itu kegiatan lomba-lomba dan pertunjukkan bakat juga dilaksanakan sebagai kegiatan yang membantu melatih rasa percaya diri. Uji kebolehan ini ditampilkan setiap peserta melalui media musik, menggambar dan membentuk kertas yang menjadi keahlian meraka. Sehingga dapat melatih soft skill dan sifat kompetitif setiap peserta dengan kemampuan yang dimiliki.

\subsection{Saran}

Memberikan pelayanan yang terbaik bagi siswa-siswi penyandang difabel melalui program khusus yang diberikan melalui pendampingan khusus oleh guru pendamping khusus maupun oleh guru reguler, dan Meningkatkan sarana dan prasarana untuk menunjang pendidikan siswa-siswi penyandang difabel dalam proses pembelajaran.

\section{Daftar Pustaka}

Sedarmayanti. Pengembangan Kepribadian Pegawai. Cetakan II. Penerbit CV Mandar Maju Bandung. 2017.

Srijanti. Etika Membangun Sikap, Graha IImu, Jakarta, 2006.

Winarti, Euis. Pengembangan Kepribadian, Graha Ilmu. Edisi Kedua. Yogyakarta. 2007. http://ulanuraeni.blogspot.com/2013/12/maka lah-bakat-dan-potensi-diri.html 